\title{
NÍSIA FLORESTA E O PIONEIRISMO "INVISÍVEL" DO FEMINISMO BRASILEIRO
}

\author{
NÍSIA FLOREST AND THE “INVISIBLE"PIONEERISM OF BRAZILIAN FEMINISM
}

\author{
https://orcid.org/0000-0003-3324-5672 Amanda Mendonça ${ }^{\text {A }}$ \\ (D) https://orcid.org/0000-0003-4962-5389 Luciana Martins ${ }^{\text {B }}$ \\ ${ }^{\text {A }}$ Universidade Federal Fluminense (UFF), Niterói, RJ, Brasil \\ ${ }^{\text {B }}$ Secretaria Municipal de Educação do Rio de Janeiro (SME-RJ), Rio de Janeiro, RJ, Brasil \\ Recebido em: 29 fev. 2021 | Aceito em: 7 out. 2021 \\ Correspondência: Amanda Mendonça (amandademendonca@gmail.com)
}

\begin{abstract}
Resumo
Em um Rio de Janeiro oitocentista, sob a égide de uma sociedade patriarcal, os principais papéis desempenhados pelas mulheres eram os de mãe e dona-de-casa. Naquela realidade, no entanto, uma figura chamada Nísia Floresta ousou contrariar esta lógica predominante. Seu trabalho e sua militância em defesa dos direitos das mulheres foram pioneiros no Brasil. Sua luta abriu vias para que hoje nós mulheres possamos estar em sala de aula, pesquisando, publicando em periódicos científicos e debatendo a atualidade de seus pensamentos. Contudo, sua trajetória e toda sua contribuição pioneira intelectualmente e na militância ainda é pouco divulgada. Assim, buscamos com este artigo, através de revisão bibliográfica, resgatar uma parte da história desta pioneira "invisível” do feminismo no Brasil.
\end{abstract}

Palavras-chave: feminismo; educação; Nísia Floresta.

\begin{abstract}
In a nineteenth-century Rio de Janeiro, under the aegis of a patriarchal society, the main roles played by women were those of mother and housewife. In that reality, however, a figure called Nísia Floresta dared to contradict this prevailing logic. Her work and activism in defense of women's rights were pioneers in Brazil. Her struggle opened the way for today women like us to be teaching, researching, publishing in scientific journals and debating the currentness of her theories. However, her trajectory and all her pioneering contribution intellectually and in militancy is still little publicized. Thus, we intend with this article, through bibliographic review, to rescue a part of the history of this "invisible" pioneer of feminism in Brazil.
\end{abstract}

Keywords: feminism; education; Nísia Floresta. 


\section{A trajetória de uma nordestina "cabra da peste"}

Nascida Dionísia Gonçalves Pinto na cidade de Papari — hoje cidade Nísia Floresta — Rio Grande do Norte, em 12 de outubro de 1810, Nísia era filha do advogado Dionísio Gonçalves Pinto Lisboa, português de personalidade progressista, casado com uma viúva brasileira. Foi obrigada a casar-se muito cedo. Aos 13 anos já era esposa de um proprietário de terras chamado Manuel Alexandre Seabra de Melo.

Já neste momento apresentava os traços marcantes de sua personalidade, que a acompanhariam por toda sua trajetória. Mesmo com tão pouca idade, Nísia enfrentou este que deveria ser o destino das mulheres de seu tempo, o casamento - acordado e forjado entre famílias - e a maternidade, ao abandonar o marido meses depois do matrimônio e retornar à casa de seus pais. Fato que para época, deixou a figura de Nísia "mal-vista" pela sociedade imperial.

É importante destacarmos que a família de Nísia se mudou diversas vezes neste período, pois havia uma forte onda antilusitana no Brasil e seu pai, conforme mencionamos, era português. Em 1828, quando Nísia completou 18 anos seu pai foi assassinado em uma emboscada nos arredores de Recife, onda a família residia, devido a uma causa judicial contra um latifundiário local. Como uma nordestina arretada e "cabra da peste" que era, Nísia assumiu a responsabilidade pela família, estudando e trabalhando.

Já na companhia de Manuel Augusto de Faria Rocha, estudante de Direito da Faculdade de Olinda e também seu grande amor, publicou seu primeiro livro e teve sua filha Lívia. Foi também neste momento que ela adotou o pseudônimo de Nísia Floresta Brasileira Augusta. Este foi um ano marcante para Nísia, pois nele ela também se mudou com a família e com Manuel Augusto para Porto Alegre. Contudo, Manuel Augusto, morreu no ano de 1833. Nísia ainda permaneceu em Porto Alegre até 1837, período em que desenvolveu vínculos de amizade com os revolucionários Anita e Giussepe Garibaldi e iniciou sua militância em diversos temas. Com a tensão da guerra dos Farrapos, mudou-se para a Corte do Rio de Janeiro, onde atuou como educadora, e inaugurou o Colégio Augusto, um precursor para o ensino feminino no Brasil.

\section{Colégio Augusto: masculino no nome, mas precursor para as mulheres}


Segundo Fausto (2004), em 1838, o Brasil passava pelo conturbado período regencial, marcado por forte instabilidade política, iniciada com a abdicação de D. Pedro I em favor de seu filho, que não pôde subir ao trono porque tinha apenas cinco anos de idade. Desta forma, foi necessário que se constituísse um governo regencial até que o futuro Imperador D. Pedro II pudesse assumir o Império.

Nessa conjuntura política, Nísia Floresta, recém-chegada à Corte, fundou o Colégio Augusto na mesma Rua do Paço Imperial, a Rua Direita, centro da Capital Federal, cenário dessas transformações políticas. A Instituição de Ensino fundada por Nísia propunha uma pedagogia diversa das que vinham sendo aplicadas até aquele momento. Era voltada à educação feminina e adotava como prática pedagógica o ensino de disciplinas que, até então, estavam reservadas aos homens. De acordo com pesquisa de Duarte (2005), esses avanços pedagógicos propostos pelo colégio não foram bem aceitos pela sociedade imperial, que considerava desnecessário que as mulheres aprendessem qualquer coisa que fosse alheia ao universo doméstico.

Sabe-se que neste período os melhores colégios da Corte, como era o caso do Colégio Pedro II ${ }^{\mathrm{i}}$, fundado sessenta dias antes do Colégio Augusto, não abriam espaço para a educação feminina. Considerava-se que o Colégio Pedro II proporcionava uma educação exemplar aos seus alunos. O seu decreto de fundação previa o ensino do Latim, Grego, francês, inglês, Retórica, Geografia, História, Filosofia, Zoologia, Mineralogia, Botânica, Química, Física, Aritmética, Álgebra, Geometria e Astronomia ${ }^{i i}$. Porém, as meninas, só começaram a ser admitidas em 1926.

Vera Cabana (1999), ao analisar a história do Colégio Pedro II, tratou das condições sociais em que viviam as mulheres no Império, o que talvez explique o desinteresse das autoridades pela sua educação:

A educação durante a monarquia estava ligada ao desempenho dos papéis sociais, enquanto a educação masculina era direcionada para o exercício da cidadania e das funções públicas, a educação feminina estava voltada para as funções familiares e para a maternidade. A sociedade era pensada a partir da célula familiar e a vida social funcionava como uma ampliação da vida doméstica. No quadro das relações sociais patriarcais, aos homens cabia formar e dirigir os núcleos familiares através da procriação, sustentação e proteção; o lugar do homem era o de administrador dos espaços privados e públicos, do micro ao macro espaço sócio-político-econômico. Às mulheres cabia o papel de reprodutoras da linhagem das famílias e zeladoras do lar; o lugar da mulher era o de esposa e mãe no âmbito doméstico e familiar, e, de forma complementar, de dama da sociedade. 
Dessa forma, na visão daquela sociedade, não havia motivo para dar uma educação à mulher equivalente à masculina, já que seus papéis sociais eram muito distintos. Se a mulher fosse educada para desempenhar bem os papéis que lhe cabiam, de esposa, mãe e dama da sociedade, era suficiente para ser considerada uma mulher instruída. Enquanto o homem deveria receber uma educação que lhe possibilitasse dominar os meios sociais, políticos e econômicos. A forma limitada como a mulher era educada, sempre voltada ao modelo tradicional estabelecido pela sociedade patriarcal é discutida por Vera Cabana (1999):

\begin{abstract}
"Ler e escrever bem em português, falar francês, declamar, conhecer música, saber dançar, receber com elegância e fazer trabalhos de agulhas, tornava as moças "cultas e prendadas" e preparadas para o casamento e para a vida em sociedade. É importante destacar que a instrução feminina não representava e/ou levava, como regra geral, à emancipação da mulher, daí o acesso feminino cortado ao Imperial Colégio, padrão do ensino oficial masculino.
\end{abstract}

O objetivo de educar a mulher era apenas o de prepará-la para o bom desempenho da vida doméstica. Até mesmo Nísia Floresta, que se preocupou com a educação feminina durante toda a sua vida, defendia que a mulher deveria ser educada, principalmente, para que pudesse educar seus filhos de forma satisfatória, mas Nísia acreditava também na capacidade das mulheres em assumir responsabilidades, que naquele momento eram exclusivas do sexo masculino:

\footnotetext{
Por que a ciência nos é inútil? Porque somos excluídas dos cargos públicos; e por que somos excluídas dos cargos públicos? Porque não temos ciência...Eu digo mais, não há ciência, nem cargo público no Estado, que as mulheres não sejam naturalmente próprias a preenchê-los tanto quanto os homens. (FLORESTA, 1847, p.52)
}

É de suma importância não dissociarmos o pensamento questionador de Nísia Floresta da realidade social em que vivia. Em uma sociedade patriarcal, na qual a valorização e o respeito social eram praticamente nulos para a mulher, qualquer conquista deveria ser considerada uma grande vitória, mesmo que a valorização venha por meio da estrutura tradicional, que infligia à mulher a obrigação de viver para outrem.

Portanto, é preciso lembrar que Nísia estava inserida nessa sociedade, e que seu pensamento foi construído a partir de conceitos e pré-conceitos, inevitavelmente, arraigados nessa cultura. Um trecho do discurso dirigido a suas educandas nos mostra que seu pensamento, por vezes, estava em consonância com a realidade de sua época: “A mulher, sendo destinada pelo criador, para amenizar existência de seu semelhante, tem para com aquele contraído a mais sagrada das obrigações, a de bem desempenhar essa sublime missão, de cujos resultados depende a felicidade de sua vida, e a de sua posteridade" (FLORESTA, 1847). 
Para Nísia, a tarefa da mulher era árdua, sua formação deveria abranger vários níveis de aprendizado, como a educação moral, intelectual e religiosa. A mulher deveria ser um exemplo de virtude. Talvez, em sua concepção, essa fosse a forma mais fácil de alcançar o respeito e a valorização social. A permanência do sistema vigente, e ao mesmo tempo a ruptura dele, comprovariam que as mulheres poderiam desempenhar de forma eficiente papéis diferentes daqueles que lhes vinham sendo impostos, além de cumprir com todas as suas tarefas cotidianas de forma satisfatória. Contudo, em seu discurso, Nísia não esquece do aconselhamento intelectual, já que esse era o diferencial proposto para a educação de suas alunas:

...não inutilizeis os esforços, que pela vossa educação se tem feito, deixando-vos de aplicar ao estudo de bons livros nas horas vagas, que vos ficarem de um trabalho proveitoso, com o qual deveis procura entreter o vosso espírito, a fim de que a ociosidade não o venha assaltar com os seus terríveis efeitos, e torná-lo incapaz de uma virtude, pela qual chegareis ao apogeu da felicidade. (FLORESTA, 1847, p.73).

No fim de seu discurso Nísia recomenda às suas alunas a prática da Santa Religião. O Colégio Augusto, apesar de inovador, conservava muitas das práticas tradicionais dos colégios do Império, uma vez que a educadora oferecia disciplinas que atendiam aos anseios da sociedade patriarcal, além daquelas inovadoras para a educação feminina, conforme artigo publicado na ocasião de sua inauguração:

D. Nísia Floresta Brasileira Augusta tem a honra de participar ao respeitável público que ela pretende abrir no dia 15 de fevereiro próximo, na rua Direita $n^{\circ} 163$, um colégio de educação para meninas, no qual, além de ler, escrever, contar, coser, bordar, marcar e tudo o mais que toca à educação doméstica de uma menina, ensinar-se-á a gramática da língua nacional por um método fácil, o francês, o italiano, e os princípios mais gerais da geografia. Haverá igualmente neste colégio mestres de música e dança... (IHGB, 1847)

Mas, apesar de não propor uma revolução imediata nos costumes, Nísia fundou um colégio voltado exclusivamente à educação feminina, e sua proposta pedagógica inovadora permitia às meninas o aprendizado de ciências, até então, reservadas apenas aos meninos. Dentre as inovações, destacamos o ensino do latim, francês, italiano, e inglês, com suas respectivas gramáticas e literaturas; o estudo da Geografia e História do Brasil; a prática de Educação Física e a limitação do número de alunas por turma, como forma de garantir a qualidade de ensino (Duarte, 1999).

Para a sociedade da época, o que Nísia ensinava às meninas, não passava de inutilidades, pois acreditava-se que à mulher bastaria a alfabetização. Às meninas só se ensinava a ler, escrever, contar, os trabalhos domésticos e os de agulha. Para Marcilio (2005), o ensino do latim era considerado indispensável aos meninos da elite, mas as meninas não 
deveriam ter acesso a este tipo de cultura. Se este era o modelo vigente de educação feminina, podemos considerar que o Colégio Augusto foi pioneiro e inovador com sua pedagogia que propunha uma educação para a mulher no nível dos melhores colégios masculinos da Corte.

Nísia também demonstrou sua preocupação com o número inferior de meninas na escola em relação ao número de meninos. A educadora afirmou que havia cinquenta e cinco mil estudantes no Império, enquanto pouco mais de oito mil deles eram do sexo feminino. Essa situação é perfeitamente compreensível se considerarmos as adversidades que cercavam a questão, como o desinteresse das autoridades em proporcionar uma educação igualitária, por conta da condição social que envolvia a figura da mulher, que era considerada um ser reprodutor que não carecia de conhecimentos que ultrapassassem as necessidades do universo doméstico.

Além da falta de qualidade, havia ainda a limitação quantitativa de escolas que atendiam ao público feminino, e consequentemente a inferioridade no número de alunas. Um outro grave problema assolava a educação feminina: somente professoras poderiam lecionar às meninas, e o salário dessas profissionais era inferior ao do professor do sexo masculino.

De acordo com Priori (1997), em 1827, foi criada a primeira lei de instrução pública do Brasil. Apesar de sua concepção de educação feminina relacionar o aprendizado da mulher ao seu papel de esposa e mãe de família, temos que reconhecer que foi um avanço para a educação feminina, pois oficializava o ensino das primeiras letras para a mulher. Mas a justificativa de educar as mulheres vinha muito clara no texto da lei:

As mulheres carecem tanto mais de instrução, porquanto são elas que dão a primeira educação aos seus filhos. São elas que fazem os homens bons e maus; são as origens das grandes desordens, como dos grandes bens; os homens moldam a sua conduta aos sentimentos delas. (LOURO, apud Lei de Instrução Pública do Brasil do Brasil, 2000, p.44)

Considerando a realidade educacional do Brasil Império, a qualidade do ensino no Colégio Augusto ficava evidente. A pedagogia inovadora propôs o ensino de disciplinas, que na maioria das vezes não era ensinada nem mesmo ao sexo masculino. Se compararmos ao tradicional Colégio Pedro II, podemos verificar que, apesar de no tocante ao pioneirismo das disciplinas ensinadas eles serem equivalentes, o Colégio Augusto deu às mulheres a possibilidade de aprendê-las oitenta e oito anos antes do Colégio Pedro II começar a admiti-las entre seus alunos.

Essa proposta educacional inovadora provocou a reação da sociedade imperial, que considerava inútil o que as meninas aprendiam no colégio de Nísia. Neste momento, começou 
a surgir na imprensa uma campanha contrária ao Colégio Augusto e a sua fundadora. A partir de então, Nísia passou a sofrer toda ordem de preconceitos.

Conforme já mencionado, o Colégio Augusto estava situado muito próximo ao Paço Imperial, fato que gerava um certo desconforto para Nísia. Até que em 1849, alegando como motivo problemas de saúde de sua filha Livia, a educadora se mudou para a Europa, onde encontrou maior receptividade para suas ideias. Entre 1949 e 1956, quando deixou de funcionar, o Colégio Augusto foi administrado por seu irmão, Joaquim Brasil.

$\mathrm{Na}$ Europa, Nísia esteve em contato com os maiores intelectuais de sua época, escreveu vários livros e viajou muito. Neste período fora do país e o contato com movimentos e intelectuais na Europa radicalizam a obra de Nísia e sua militância em defesa dos direitos das mulheres.

\section{A militante Nísia}

Conforme mencionamos, o principal foco da militância de Nísia Floresta sempre foi a defesa dos direitos femininos, principalmente através da argumentação do direito ao acesso à educação. Foi essencialmente a esta luta que ela dedicou sua vida e seu trabalho, como educadora e escritora. Desde sua estreia na literatura, em 1831, no Jornal Espelho das Brasileiras, de Pernambuco, Nísia escrevia sobre a condição feminina em diversas culturas antigas:

\footnotetext{
...seria impossível abranger nos limites dessa folha todas as ações ilustres praticadas pelas senhoras romanas, nessa época feliz; todavia é do nosso dever citar para honra do sexo feminino, e confusão de seus injustos detratores, os principais feitos dessas verdadeiras heroínas, cujo patriotismo provou a que ponto as mulheres, sem jamais se intrometerem na repartição dos homens, podem ser úteis nas crises, que ameaçam a segurança do estado. FLORESTA apud DUARTE, 1995, p. 23)
}

Na publicação de seu primeiro livro, Direitos das Mulheres e Injustiça dos Homens, publicado em 1832, é que conhecemos Nísia Floresta Brasileira Augusta. Seu segundo livro, Opúsculo Humanitário, de 1853, foi publicado quando já estava na Europa. Percebemos uma mudança ideológica no pensamento de Nísia entre as duas obras que tratam da defesa dos direitos das mulheres. Na primeira, Nísia é clara ao rejeitar qualquer mudança radical na estrutura social vigente, como no trecho a seguir:

De quanto tenho dito até o presente não tem sido com a intenção de revoltar pessoa alguma do meu sexo contra os homens, nem de transformar a ordem presente das coisas, relativamente ao governo e autoridade. Não, fiquem as coisas no seu mesmo estado. (DUARTE 2005, p. 209) 
Na verdade, não há como saber se essa proposta de manutenção da estrutura social era realmente ideológica ou se era uma forma de tentar amenizar suas críticas ao modelo vigente. O fato é que vinte e um anos depois, vivendo na Europa, Nísia muda o tom de seu discurso em defesa das mulheres. Em seu segundo livro sobre o assunto, Nísia é mais contundente em suas críticas, chegando a afirmar que:

Não poderá haver no Brasil uma boa educação da mocidade, enquanto o sistema de nossa educação, quer doméstica, quer pública, não for radicalmente reformado...quanto mais ignorante é um povo, mais fácil é a um governo absoluto exercer sob ele o seu ilimitado poder. (DUARTE, 2005)

Mas é preciso enfatizarmos seu pioneirismo na luta das mulheres no Brasil e mesmo antes de sua ida para Europa, onde radicalizou sua defesa e trouxe novos argumentos, enriquecendo seu arcabouço teórico no campo da defesa da igualdade entre homens e mulheres. Ainda em 1832, quando nem havia chegado ao Rio de Janeiro, ela escreveu uma tradução livre de Vindication of the Womam, de Mary Wolstonecraft, que segundo especialistas nos estudos feministas, seria a obra fundadora do feminismo no Brasil.

A obra contém a denúncia sobre o estado de inferioridade em que viviam as mulheres de seu tempo:

Se cada homem, em particular, fosse obrigado a declarar o que sente a respeito de nosso sexo, encontraríamos todos de acordo em dizer que nós somos próprias se não para procriar e nutrir nossos filhos na infância, reger uma casa, servir, obedecer e aprazer aos nossos amos, isto é, a eles homens... Entretanto, eu não posso considerar esse raciocínio senão como grandes palavras, expressões ridículas e empoladas, que é mais fácil dizer do que provar. (FLORESTA, 1989, p. 35)

Se sua militância pelos direitos femininos aparece tímida nas páginas desta primeira obra. Em Opúsculo Humanitário, de 1853, ela aparece de forma explicita e Nísia é contundente suas afirmações e reivindicações de igualdade entre os gêneros.

Em suas obras Nísia expunha sua insatisfação com a condição social das mulheres de sua época, ao mesmo tempo em que acusava o sexo masculino de colocá-las sob o estigma da inferioridade. Suas palavras demonstram que, apesar de não ter proposto em seus livros uma revolução nos costumes, a condição em que a mulher era colocada a incomodava. Seus artigos e sua militância despertou a ira de muitas figuras "ilustres", como a de Gilberto Freyre.

Gilberto Freyre analisava o papel exercido pela mulher na sociedade patriarcal do Império como secundário. Seu texto demonstra a dimensão do preconceito contra mulheres que conquistaram alguma posição de destaque naquela sociedade:

...Nísia Floresta surgiu - repita-se - como uma exceção escandalosa. Verdadeira machona entre as sinhazinhas dengosas do meado do século XIX. No meio dos 
homens a dominarem sozinhos todas as atividades extra domésticas, as próprias baronesas e viscondessas mal sabendo escrever, as senhoras mais finas soletrando apenas livros devotos e novelas que eram quase histórias do Trancoso, causa pasmo ver uma figura como a de Nísia. (DUARTE, 2005, p.13)

Causava- e ainda causa- estranheza quando uma mulher fugia do padrão estabelecido pela sociedade. Havia até um biótipo considerado o ideal para as moças de família, que deveriam aparentar fragilidade, candura, enfim, a mulher tinha que ser inofensiva e demonstrar essa característica em sua aparência e atitude. E Nísia enfrentava tudo isso. Ela não era frágil, não era do lar, não era padrão. Ela dizia:

\footnotetext{
Não nos embala a vã pretensão de operar uma reforma no espírito de nosso país. Por demais sabemos que muitos anos, séculos talvez, serão precisos para desarraigar herdados preconceitos a fim de que uma tal metamorfose se opere. Esperamos somente que os zelosos operários do grande edifício da civilização em nossa terra atentem para os exemplos que a História apresenta do quanto é essencial aos povos, para firmarem a sua verdadeira felicidade, o associarem a mulher a esse importante trabalho. A esperança de que, nas gerações futuras do Brasil, ela assumirá a posição que lhe compete nos pode somente consolar a sua sorte presente. (DUARTE, 2005, p.209)
}

Mais uma vez Nísia Floresta mostra seu inconformismo com a condição das mulheres e responsabiliza o sexo masculino por uma futura mudança no quadro de desvalorização e inferioridade aos quais a sociedade as submetia.

\section{A Questão Abolicionista para Nísia Floresta}

Novamente Nísia demonstra o caráter pioneiro de sua militância. Vivendo no Rio de Janeiro, Nísia participou de conferências, nas quais se discutiam a Abolição dos Escravos e a República, conforme analisa a escritora Ignez Sabino (1996):

Olhando para a política do seu país ainda escravocrata, aqui em 1842, tentou umas conferências públicas que aliás foram concorridas pelo que de mais seleto havia. Saíam daí deslumbrados não só pela presença agradável da jovem senhora, como pela audácia de sua inteligência de primeira água e ainda mais... um horror para aquele tempo. Por ousar a ilustre dama falar em abolição e em federalismo.

Em 1842, ela já militava pela abolição dos escravos, quando a disseminação dos ideais anti-escravocratas aconteceu apenas a partir de 1860. Há ainda um registro em 1909, sobre o ineditismo de Nísia em pregar publicamente o abolicionismo em 1840. Porém, é um dos poucos registros, já que não houve notícias na imprensa, nem a publicação de tais conferências.

Nísia publicou em Páginas de uma Vida Obscura, de 1855, o drama vivido pelo escravo no Brasil e expôs seu sentimento com relação à escravidão. Esteve entre as primeiras vozes femininas a se manifestarem a favor da abolição, ainda que de forma contida, pois o movimento 
abolicionista ainda não estava amadurecido. Além disso, os leitores provinham das classes mais abastadas, comprometidas com o latifúndio e o escravismo. Porém, em 1864, vivendo há mais de 10 anos na Europa, Nísia se sentia mais à vontade para defender seus ideais abolicionistas com a publicação do livro Trois ans en Italie, no qual faz um apelo humanitário em favor dos cativos ao escrever que a escravidão era a vergonha da civilização moderna e que os europeus deviam "se envergonhar de pôr sua inteligência a serviço da violação das leis mais santas da natureza e da moral, e de acorrentar seu semelhante em uma escravidão perpétua".

A Europa, berço das ideias liberais, às quais Nísia teve acesso ainda no Brasil, era o lugar perfeito para a escritora pôr em prática sua militância de forma plena, o que não podia fazer no Brasil. Pois na Corte os abolicionistas eram vistos com restrições, principalmente se o militante fosse do sexo feminino.

Almeida (2004) atribuiu à Nísia grande poder de influência, já que, segundo ele, seus escritos sobre a escravidão nos idiomas francês e italiano, tinham considerável circulação entre os mais altos intelectuais da Europa e contribuíram para preparar a intervenção da Junta Francesa de Emancipação, em 1866, junto ao imperador, pedindo-lhe a abolição da escravidão no Brasil.

Para uma escritora humanista e de ideologia liberal, como Nísia Floresta, não devia ser uma tarefa fácil vivenciar o dia a dia de uma sociedade escravista que havia perdido a capacidade de perceber sua condição desumana de exploração, e ao mesmo tempo, de dependência daquele regime.

A crítica ao regime escravista apareceu nos livros publicados por Nísia Floresta. Em Opúsculo Humanitário, de 1853, publicado quando a escritora já vivia na Europa há quatro anos, as referências à escravidão são mais frequentes e claras. Nesta obra a escritora denuncia o tráfico humano, a utilização do negro como animal de carga e o tratamento rude que era dispensado aos escravos por seus senhores.

Em Páginas de uma Vida Obscura, seu único livro tratando exclusivamente da escravidão, Nísia conta a história de um escravo, filho único e herdeiro do chefe de sua tribo africana, que é aprisionado e trazido para o Brasil. Nesta obra, a escritora trabalha com a mesma problemática de Gilberto Freyre, a escravidão paternalista, já que aponta para uma relação de generosidade do senhor e de gratidão e fidelidade do escravo.

A intenção de Nísia naquele momento em que o movimento abolicionista ainda não tinha atingido sua maturidade, talvez fosse propor uma relação mais humana, mais branda entre escravos e senhores. Ela não poderia ser contundente em suas afirmações contrárias ao regime 
escravista, mas poderia deixar uma sugestão de um comportamento amigável, onde o negro fosse mais humanizado. Nos parece uma tentativa de acordo entre as partes, e de normatizar as relações escravistas, de forma que a tornasse menos violenta, como nos mostra um diálogo entre dois escravos, personagens do livro:

Um bom senhor é imagem de Deus sobre a Terra, onde as leis permitem o triste tráfico
da nossa espécie. Podendo castigar-nos quando faltamos ao cumprimento de nossos
deveres, ele nos admoesta paternalmente; sendo-lhe permitido por-nos ao nível dos
brutos, ele nos governa com brandura trata-nos quando doentes como a seus próprios
filhos. É pena que todos assim não sejam! Mas confessemos que são ordinariamente
os mesmos escravos a causa do mau tratamento que recebem.

O discurso do escravo contém, sutilmente, uma denúncia da violência praticada pelo seu senhor. Mas há também a sugestão da passividade do escravo diante de sua situação de cativo. A mensagem de Nísia fica subentendida, ela pede que o escravo seja passivo, a fim de angariar a boa vontade de seu senhor, e assim evitar os castigos violentos. Entretanto, o que Nísia não diz é que a maior violência não é o castigo físico, mas o próprio cativeiro, a privação da liberdade, a dominação de um homem sobre outro.

Contudo, seu pensamento se desenvolve. Anos depois, vivendo na Europa, em contato com filosofias humanistas, a autora aborda o mesmo assunto sob uma nova perspectiva. Nísia deixa de tratar a escravidão como uma simples subjugação do negro pelo branco, mas, a partir de uma visão mais ampla da questão, trata da dominação despótica de um ser sobre o outro.

Possam os governos de todos os países civilizados escutar os gritos da agonia prolongada desses desgraçados oprimidos, brancos e negros! E que a libertação geral dos escravos no Novo como no Velho Mundo, assimilando uma das mais gloriosas épocas nos anais da Humanidade, evidencie a elevação das ideias do século dos maravilhosos progressos intelectuais! (FLORESTA, 1864, p. 158)

A liberdade de pensamento e de expressão que a Europa proporcionou à Nísia Floresta ficam evidentes, quando verificamos a quantidade de obras produzidas pela escritora a partir da mudança para aquele continente. Mas o desenvolvimento não foi apenas quantitativo, a diferença na qualidade de sua produção literária também fica clara. Em nossa percepção, há maior clareza e liberdade na exposição de suas ideais.

\section{A história que a história não conta}

O nível educacional das mulheres na Corte era muito baixo. A maioria delas não saia sequer da condição do analfabetismo, pois a maior preocupação das famílias era formá-las para desempenhar bem os papéis que lhes cabiam, de esposa, dona-de-casa e mãe. Uma vez que bastaria esse aprendizado para arranjarem um casamento, que era uma condição primordial para 
que a mulher estivesse integrada à sociedade. Os homens recebiam uma educação superior à feminina e detinham o poder social, portanto dominavam os espaços públicos e privados, enquanto a mulher estava limitada à maternidade, necessária para manter a linhagem do marido.

Percebemos no pensamento intelectual oitocentista a curiosidade pelo comportamento e fisiologia femininos. Aquele meio se esforçava para desvendar a mulher, descobrir as especificidades do gênero. Alguns apelaram para a biologia, a fim de comprovar suas teses. Porém, outros explicaram as diferenças culturalmente, se aproximando do que acreditamos hoje ser a melhor explicação para as diferenças entre os sexos.

A mulher da sociedade imperial, ao contrário da ideia corrente, não estava conformada com sua condição de desvantagem com relação ao universo masculino. O que ocorria com ela era a impossibilidade de se manifestar, ela não tinha voz ativa. À mulher não era permitido expor seu pensamento, ela deveria se submeter às vontades do pai e depois do marido. Além de se calarem, deveriam ainda demonstrar fragilidade, timidez e submissão. Este era o estereótipo da moça de boa família. Não foram poucas as vezes que as que tentaram fugir dos padrões estabelecidos pela sociedade acabaram seus dias em hospitais psiquiátricos. Uma vez que era mais fácil atribuir qualquer reação feminina à loucura, que à insatisfação com os papéis que lhe impunham. O que demonstra insegurança do mundo masculino, que ao sentir qualquer ameaça ao monopólio do poder, reagia a fim de neutralizá-la.

O mundo que cercava a mulher branca das classes mais altas era de aparências, no qual cada um representava um papel ${ }^{\mathrm{iii}}$. A mulher, como a criatura frágil, enquanto o homem deveria ser a representação da moral e da virtude. Mas na verdade a ele eram permitidos certos deslizes perdoados pela boa sociedade. Já que seus descendentes eram muitas vezes criados pelas próprias esposas, condição que parecia tolerável aos olhos da sociedade.

Portanto, a sociedade do Rio de Janeiro Imperial era essencialmente patriarcal. Os homens controlavam-na, enquanto mantinham suas mulheres enclausuradas em suas casas, procriando, muitas vezes, mais de uma dezena de herdeiros. A sociedade lhes negava direitos, viviam praticamente num cativeiro doméstico. Enquanto seus maridos tinham assegurados todos os direitos e privilégios que o patriarcado lhes garantia.

Essas condições desiguais entre os sexos, que desfavoreciam sempre as mulheres, potencializam o mérito do trabalho de Nísia Floresta, pois quando apresentamos situações que envolvem mulheres do período imperial e a militância de Nísia, parece tratar-se de dois universos diferentes, o que nos indica que havia um abismo entre a realidade da maioria das mulheres da Corte e a de Nísia Floresta. Seu papel questionador cumpriu o objetivo, ainda que 
restrito, de abalar as estruturas sociais do império. Pois se ela incomodou de alguma forma aquela sociedade, provavelmente, em algum momento provocou a polêmica acerca de seus posicionamentos.

O caráter questionador de Nísia fica claro ao analisarmos alguns aspectos de sua vida, como sua amizade com Anita e Giuseppe Garibaldi, na época em que viveu em Porto Alegre. Ainda que de forma comedida, a escritora abordou temas polêmicos que a tornaram uma figura considerada perigosa para o império.

Nísia Floresta é considerada a precursora dos ideais feministas no Brasil. Desde o início de sua carreira literária a defesa dos direitos femininos foi o tema mais recorrente em sua obra. E trazer esse tema polêmico à tona naquela sociedade patriarcal deve ter gerado a insatisfação de muitos, principalmente após a inauguração do Colégio Augusto, que punha em prática as reivindicações de Nísia com relação à educação feminina. Por este motivo, a educadora começou a sofrer com a campanha contrária dos jornais cariocas, como o jornal do comércio (1838), que consideravam as propostas educacionais do Colégio avançadas e inadequadas: "Trabalhos de língua não faltaram, os de agulha ficaram no escuro. Os maridos precisam de mulher que trabalhe mais e fale menos".

Os jornais eram implacáveis quando o assunto era a pedagogia proposta pelo Colégio Augusto. As disciplinas ensinadas por Nísia eram consideradas desnecessárias para a educação de uma menina, como insinua o artigo de O Mercantil:

...Há casas de educação que têm o mau gosto de ensinar às meninas a fazer vestidos
ou camisas. Mas parece que D. Augusta acha isso muito prosaico. Ensina-lhes latim.
E porque não grego e hebraico? Pobre diretora! Está tão satisfeita de si mesma e de
seu colégio; está tão intimamente persuadida que é o primeiro estabelecimento de
instrução do império, que, em verdade causa dó arrancar-lhe tão suave ilusão!...É pois
natural que D. Nísia que nunca viu senão o próprio colégio o ponha acima dos demais.
Há mais nesta opinião mais ingenuidade do que vaidade. Notaremos apenas a D.
Floresta que se esquece um tanto do verdadeiro fim da educação, que é o de adquirir
conhecimentos úteis e não vencer dificuldades, sem nenhuma utilidade real. (BNRJ,
1847)

A figura de Nísia Floresta esteve sempre envolta em polêmicas e preconceitos. Sua ousadia em defender uma mudança na estrutura de uma sociedade patriarcal, que via a mulher como um ser inferior, lhe custou um alto preço. O maior deles foi ser obrigada a viver longe de seu país, pois a partir de 1849 foi viver na Europa, onde suas ideais liberais eram acolhidas com maior receptividade, já que no Brasil não havia mais espaço para que pudesse expor seu pensamento.

Em sua terra natal, o Rio Grande do Norte, todo tipo de histórias surgiu a seu respeito. Foi tachada de indecorosa e atrevida. Os conterrâneos se envergonhavam de terem a mesma 
origem de Nísia. Essa situação perdurou mesmo após sua morte, em 1885. Hoje, seus restos mortais repousam na praça principal da cidade, vindos da França em 1954. Surgiram lendas envolvendo seu nome, como a de que Nísia se levantava do túmulo durante a madrugada para "agarrar" os homens da cidade. O que obrigou a prefeitura a envolver seu túmulo com correntes, para conter o pânico entre os moradores.

Acreditamos que o preconceito e a difamação relegaram Nísia Floresta, praticamente ao anonimato, já que apesar de sua importância social, principalmente com relação à história de luta pelos direitos femininos, sua obra ainda é pouco conhecida no Brasil. Em geral, restrita aos historiadores da educação e às feministas. Alguns de seus livros são encontrados em bibliotecas na Europa, sem que haja um único exemplar em seu próprio país. Seu nome é quase que completamente desconhecido, pois não havia interesse de seus contemporâneos em preservar sua memória, ao contrário, queriam esquecer da mulher que incomodava àquela sociedade, que militava por causas que não interessavam que fossem trazidas à discussão. Manter viva a memória de uma mulher que ousou questionar as estruturas de uma sociedade patriarcal não era interessante.

Sua partida para a Europa, onde viveu o resto de sua vida, contribuiria para mantê-la apagada da memória dos brasileiros. Entretanto, paradoxalmente, os mesmos motivos que a mantiveram longe de seu país, ajudaram a difundir seus ideais entre a intelectualidade europeia, sua ousadia e seu pensamento liberal. Então, a tentativa de apagar sua memória no Brasil, acabou sendo frustrada pela acolhida que suas ideais tiveram na Europa, onde Nísia produziu uma extensa obra literária.

Há ainda pouca bibliografia disponível sobre a vida e obra de Nísia, mas toda ela aponta para uma mulher e uma militante que rompeu uma série de barreiras, que pareciam intransponíveis para as mulheres de seu tempo. Uma mulher erudita, quando a maioria era sequer alfabetizada. Uma mulher que militava pelas causas nas quais acreditava, e produziu extensa obra literária, além de ter publicado artigos em jornais. Nísia quebrou uma série de paradigmas, e seu legado, apesar da tentativa de lhe imporem o esquecimento, ficou para as gerações posteriores, que continuaram militando em prol dos direitos femininos.

Mas apesar de seu nome ter sido mantido no ostracismo, Nísia Floresta hoje é lembrada pelos estudiosos pelo pioneirismo de seu colégio, de sua obra literária e de sua militância. Esse pioneirismo foi um dos primeiros passos dados em direção às conquistas da mulher na sociedade, já que Nísia reivindicava principalmente direito ao acesso à educação, mas nas gerações seguintes surgiram outras vozes clamando por direitos políticos, civis e econômicos. 
Percebe-se em todos os momentos da História do Brasil e do mundo, a participação de mulheres nos ambientes públicos dominados essencialmente pelos homens. A tentativa de subjugá-las surtiu efeito na grande maioria das vezes, entretanto, algumas poucas mulheres resistiram e atuaram em áreas diversas. Dessa minoria, algumas passaram incógnitas pela história por sobressaírem apenas num pequeno grupo, mas nem por isso sua luta pela igualdade entre homens e mulheres teve menos importância. Outras, como Nísia, deixaram seus nomes registrados na história.

Neste caso, apesar da tentativa de relegarem sua memória ao anonimato, apagarem seu nome e sua história, sempre existirão mulheres que como Nísia, lutaram para mudar o Brasil. Acreditamos que hoje, uma contribuição importante, é conhecermos nossa história e as mulheres que fizeram parte dela, que construíram nosso país, em cima dos "versos que o livro apagou...Mulheres, tamoios, mulatos...Eu quero um país que não está no retrato.”

\section{Referências:}

ALENCASTRO, Luiz Felipe de e NOVAIS, Fernando (org.). História da Vida Privada no Brasil. São Paulo: Companhia das Letras, 1997.

ALMEIDA, Adjovanes Thadeu Silva de. Nísia Floresta: Mulher e Educadora no Brasil Imperial. In: Encontros: Revista do Departamento de História do Colégio Pedro II, nº3, março, 2004, p. 57-66.

ANDRADE, Vera Lúcia Cabana de Queiroz. Colégio Pedro II - Um Lugar de Memória.Rio de Janeiro. UFRJ. Tese de Doutorado, 1999.

ARIÈS, Philippe e DUBY, Georges (org.). História da Vida Privada. São Paulo: Companhia das Letras, 1991.

BARMAN, Roderick J. Princesa Isabel do Brasil: Gênero e Poder no Século XIX. São Paulo: UNESP, 2005.

CASTRO, Luciana Martins. A contribuição de Nísia Floresta para a educação feminina: pioneirismo no Rio de Janeiro oitocentista. Outros tempos - Dossiê História e Educação, volume 7, número 10. Rio de Janeiro, 2010. p. 237-256.

DUARTE, Constância Lima. Nísia Floresta: Vida e Obra. Natal: UFRN, 1995.

Mulheres, 2002.

, Constância Lima (org.). Cartas: Nísia Floresta e Auguste Comte. Florianópolis:

, Constância Lima. De Papari para o Mundo. In: Revista de História da Biblioteca Nacional, $\mathrm{n}^{\circ}$ 6, dezembro, 2005, p. 53-56. 
FAUSTO, Boris. História do Brasil. São Paulo: EDUSP, 2004, p. 161 - 171.

FILHO, Adolfo Morales de los Rios. O Rio de Janeiro Imperial. Rio de Janeiro: Topbooks, 2000.

FREYRE, Gilberto. Sobrados e Mucambos. São Paulo: Global, 2004.

FLORESTA, N. Direitos das mulheres e injustiça dos homens. São Paulo: Editora Cortez, 1989. . Vida Social no Brasil nos Meados do Século XIX. Recife: Massangana, 1985.

GERSON, Brasil. História das Ruas do Rio. Rio de Janeiro: Lacerda Editores, 2000.

LEITE, Miriam. A Condição Feminina no Rio de Janeiro, Século XIX. São Paulo: EDUSP, 1993.

LOBO, Yolanda e FARIA, Lia. Vozes Femininas do Império e da República. Rio de Janeiro: FAPERJ, 2008.

LOURO, Guacira Lopes. Mulheres na sala de aula. In: DEL PRIORE, Mary (org.). História das mulheres no Brasil. $3^{\text {a }}$ ed. São Paulo: Contexto, 2000.

MARCÍLIO, Maria Luíza. História da Escola em São Paulo e no Brasil. São Paulo: Imprensa Oficial do Estado de São Paulo, 2005.

PERROT, Michelle. Minha História das Mulheres. São Paulo: Contexto, 2007. . As Mulheres ou Os Silêncios da História. Bauru: EDUSC, 2005.

PRIORI, Mary Del (org.). História das Mulheres no Brasil. São Paulo: Contexto, 1997.

RENAULT, Delso. O Rio Antigo nos Anúncios de Jornais. Rio de Janeiro: Francisco Alves, 1985.

SABINO, Ignez. Mulheres Ilustres do Brasil. Rio de Janeiro: H. Garnier, 1899. Edição facsimular. Editora, 1996.

SAMSON, Adèle Toussaint. Uma Parisiense no Brasil. Rio de Janeiro: Capivara, 2003.

SOIHET, Raquel. Condição Feminina e Formas de Violência, Mulheres Pobres e Ordem Urbana, 1890 - 1920. Rio de Janeiro: Forense Universitária, 1989.

TELES, Maria Amélia de Almeida. Breve História do Feminismo no Brasil. São Paulo: Brasiliense, 1993.

\section{FONTES HISTÓRICAS}




\section{BNRJ}

Jornal do Comércio - 31 de janeiro de 1838 - Cód. PRC - SPR 1.

- Anúncio sobre a fundação do Colégio Augusto.

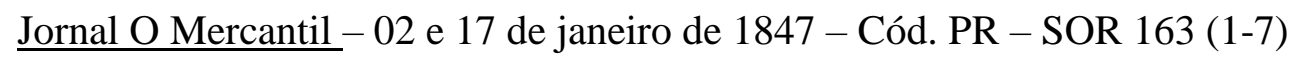

- Campanha contrária ao Colégio Augusto.

Discurso que a suas Educandas Dirigiu N. F. B. Augusta - 18 de dezembro de 1847 - Typ. Imparcial de F. de Paula Brito, Rio de Janeiro - Cód. 040/A941p.

- Discurso proferido por Nísia Floresta na formatura de suas alunas no ano de 1847.

FLORESTA, Nísia. Opúsculo Humanitário. São Paulo: Atual, 1989. Localização: IV-316,3,17.

- Livro publicado por Nísia Floresta em 1853, que trata do preconceito contra a mulher e dos erros cometidos na sua formação educacional.

FLORESTA, Nísia. Direitos das Mulheres e Injustiça dos Homens. São Paulo: Cortez, 1989. Localização: I-67,5,44.

- Livro publicado por Nísia Floresta em 1832. É uma tradução livre do livro Vindication of the Rights of Woman, de Mary Wollstonecraft, que trata da denúncia do estado de inferioridade em que se encontravam as mulheres de seu tempo.

\section{IHGB}

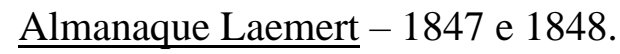

- Traz um anúncio sobre o Colégio Augusto.

\section{COLÉGIO PEDRO II}

\section{NÚCLEO DE DOCUMENTAÇÃO E MEMÓRIA (NUDOM)}

Decreto de fundação do Colégio Pedro II, de 02 de dezembro de 1837.

O Colégio Pedro II nos últimos 10 anos - 1927 - 1937. Rio de Janeiro: Tipografia Alba, de Moreira, Cardoso e Freitas, 1937.

\footnotetext{
${ }^{i}$ Em seu decreto de criação, não especificou destinar-se exclusivamente à educação de meninos. Segundo os costumes da época, no entanto, era essa a clientela possível. O ingresso das mulheres no corpo discente do Colégio somente efetivou-se noventa anos após a sua fundação, em 1927.
} 


\begin{abstract}
ii Decreto de 02 de dezembro de 1837 - Fundação do Colégio Pedro II - NUDOM, Colégio Pedro II, Unidade Centro.

iii Registro das autoras que este texto e suas análises sobre o patriarcado e as desigualdades sobre os papéis sociais impostos para homens e mulheres na sociedade oitocentistas estão restritos a elite branca. Não há recorte racial neste texto. Sabemos que para as mulheres negras este processo e seus impactos se dão de maneira diferenciada.
\end{abstract}

